\title{
Sinteza
}

Impact of Internet on Business Activities

\section{IMPROVING CUSTOMER RELATIONSHIP MANAGEMENT USING MODERN INFORMATION TECHNOLOGY IN HOTEL INDUSTRY}

\author{
Dušan Borovčanin \\ Singidunum University, Belgrade, Serbia
}

\begin{abstract}
:
Exponential growth and development of information technology in the late twentieth and early twenty-first century have dramatically affected the operations of companies from many industries, including companies in the tourism and hospitality industry. Their application imposed itself as a key factor for companies in order to retain their positions in the market. At the same time, the hotel companies are challenged by even more educated consumers, who react very quickly on any change nowadays, and in line with it, they expect well designed offer for them. Nowadays, users of hotel's services have much more information on their disposal, than it was the case twenty years ago. Therefore, they carefully make a decision about which company to place their trust. This situation does not necessarily have to be aggravating for hoteliers. On the contrary, it can be used as a reason to build even stronger relationships between the client and the company, and the development of increasing loyalty among existing customers.
\end{abstract}

\section{Key words:}

Customer Relationship

Management.

\section{INTRODUCTION}

"The modern business, including hospitality, is characterized by large amounts of information" [1]. The real challenge for hotel managers is an information management, actually the separation between information that is less or more important. Based on all the information available, a hotel manager must carefully make the right and timely decision, based on the idea that the client is always in the center of his focus, with a care to sustainable growth and development of the company. In modern business, the largest part of this work is done with the help of modern information technology. They serve as a kind of tool for collecting, processing and analyzing large amounts of information that are important for hoteliers. "Today's challenge for organizations is not only to provide information to people who run a business, but enabling all entities to access and collaborate over the same information as and when the need arises"[2].

Today, it is virtually impossible to imagine a serious hotel company located in a developed destination, especially in urban areas, which is in the process of making various decisions, including improving sales and building customer relationships, and which is not relying on the latest solutions in the field of information technology. This does not apply only use, and of course, the placement of various information via the Internet, but developing and using specific PMS (Property management System) and CRM (Customer Relationship Management) system.

\section{THE DEVELOPMENT OF INFORMATION SYSTEMS IN HOSPITALITY}

Right at the beginning it should be noted that hotel companies do not represent leaders when it comes to the introduction of modern information technology into their business. They do it later compared to many other companies in other industries, but also with a certain delay compared to companies that are primarily engaged in tourism. True leaders actually were airlines, that have developed their first GDS (Global Distribution System) in the early sixties. It was actually sort of a B2B model which was used to support the sales of airline companies, and for agencies which represented among other things intermediaries in the sales of airline tickets, the decrease of costs, because, suddenly it became possible to process a greater number of requests per unit of time. 
"The first computer reservation system was "HOLIDEX" by " Holiday Inn", which in 1987 included rooms at over 1900 hotels worldwide, updating annually 30 million overnight stays per room. Similar systems have been developed for other major hotel chains, such as: Ramada (RENOIR), Marriott (Marsh), Crest (Crestar II), Intercontinental (Global II), Hilton (Hilton), Foret (Inn) and Sheraton (Reservator IV)"'[1]. As a matter of fact, any development of new information systems and the creation of new software, aims to replace the current way of manually processing different data. Today, however, IT solutions in the hotel business do not have only the function of the cost-effectiveness. Modern software became practically hotel manager advisors in the decision making process, through the use of intelligent and integrated information technology. According to Čačić, PMS (Property Management System) is a basic component for managing hotel operations.

It is used to perform daily operations, and its main areas are:

- Operational management of the hotel business (hotel management, inventory management, facility cleaning ... etc.)

- Accounting and bookkeeping

- front office

- Sales and marketing

- Human Resource Management

- Culinary Business"[3].

One of the leaders in this field is certainly the MicrosFidelio, the best known global solution that was created after the collaboration of two different companies. 'Micros System", originally from the territory of the United States, and "Fidelio" with headquarters in Munich. Today, Micros-Fidelio is a global giant with more than 300,000 installations worldwide. The reason for this wide application of Micros-Fidelio is its functionality and simplicity of use. "It is worth mentioning that CRM is mainly based on the belief that establishing a sustainable relationship with customers is the cornerstone for obtaining loyal customers who are much more profitable than non -loyal ones '[7] .

Everything mentioned should be based on a well-executed prior analysis of all operations which opportunities for further development spread on a daily basis.

\section{IMPLEMENTATION OF INFORMATION TECHNOLOGY IN HOSPITALITY}

Proper use and continuous improvement of various software solutions in the hotel is one of the imperatives imposed in order to survive in the market. This means that the mere introduction of CRM and PMS systems in hotel will not necessarily lead to changes in the business if they are not used in accordance with the potential they possess. Because of the different modules that are intertwined, and that are combined by the systems such as Micros-Fidelio, it is necessary to train staff (personnel) so that they become capable of collecting a large number of information that will be entered into the system.
As already mentioned, accurate and timely information in modern business are almost priceless. Thus, for example, if an employee who is in the first line of communication with the guest is not sufficiently trained, and if he omits to enter specific information in the system which is important for the hotel manager, he(the hotel manager) could make an incorrect estimate that is based entirely on the human factor.

Therefore, large companies that provide services based on these information technologies to hotels, offer employee training programs as well. These IT software solutions also allow a diverse access to the information, when it comes to employees. This is, of course, quite natural, because not all information will be available to all employees at all times. However, this type of restriction requires careful planning of information access, prior to the introduction of a complete system in the hotel. This means that you need to predict in advance which information, for example, a receptionist will be able to change, and which ones only to read. Also, the practice that prevailed and that is current in GDS systems, and which applies to leaving a trace on which person carried out certain changes in the system, has been taken, and implemented in CRM and PMS systems. This feature reduces the possibility of abuse, and as such represents an additional measure of precaution and control. Implementation of information technology in the hotel, especially CRM and PMS systems entails certain costs.

Hotel manager must plan the total costs of implementation of these systems, and the additional costs for the department of technical services, where a certain employee, or several of them will be in charge of software servicing. A hotel manager can even establish a specific IT service department, engaged in activities of this kind. Smaller enterprises, in turn look forward to a various forms of outsourcing engagements, to maintain their costs to a minimum. Given all the above, it is clear that the benefits from the introduction of information technologies in the business are far greater, in respect of all flaws.

\section{POSSIBILITIES TO BUILD RELATIONSHIPS WITH CUSTOMERS BY MEANS OF INFORMATION TECHNOLOGY}

Many years ago the relationship between the buyer and the seller, or service providers and service recipients surpassed only transactional form. Therefore, nowadays managers are increasingly paying attention to the attitudes of consumers, and they are actively examining their wants and needs. They are constantly working to deliver the highest possible value for them, so that, at the end they become capable of building a partnership relation with their consumers, with the aim of creating loyal customers who are, of course, much more cost-effective. All these facts are even more important for companies that are exclusively engaged in providing services, like hotels, where the contact between service users and service provider is pretty direct. In addition, if we know that the timing of manufacture and the delivery of services takes place at the same time, questions like how to deliver these services, 
who and in what way to provide them become crucial. Information technologies include a number of factors that make the process of service providing much more perfect, and increase the possibility of creating real value for consumers. "The goal of every company is to increase the delivered value, and achieve added value for consumers, and thereby win their affection and loyalty" [4].

Some of the factors that information systems provide, and this primarily refers to PMS systems are: cost-effectiveness, availability, flexibility and analyticity. Each of these factors can be observed in two separate ways. Either from the angle of the user, either the angle of service provider, in this case a hotel company.

Cost-effectiveness of the company is reflected in the ability to handle a number of different requests per unit of time, as well as in the fact that all data is available for printing at any time, and that it saves material costs and storage space. On the other hand, faster data processing provides savings in time for the customer.

The information availability is certainly of great importance for the service user. Guests can enjoy access to the availability of capacity, and the possibility of making a reservation at the best price, at any time, using almost every device that has internet access. On the other hand, a possibility of having the insight in some internal data at any time for hoteliers represents an exceptional benefit. An immediate insight into the percentage of capacity occupancy, information about the average room price, or the cash flow information, for example, represent something that was virtually unthinkable 20 years ago.

Flexibility is also a factor that can be scouted from two different angles. The company's capability to adapt to the needs and desires of consumers, on the basis of previously collected information, with the help of information technology is far greater. In contrary, the user is given the opportunity to really be conducted in line with his needs, and to choose the best customized offer.

Finally, possibility to make their own analysis is incomparably easier for the company with the help of CRM and PMS systems. The possibility of making the analysis of the average occupancy in the previous period, and the ability to predict the average occupancy in the coming period, and the projection of the optimal level of prices are just some of the privileges. Conversely, when it is said analyticity for the user, it is referred to the ability to compare a large number of offers and prices, and making the best decision on those bases.

Having in mind all these factors, hotel manager needs to make a decision for what purposes will he use information technology. Some of the features that enhance the prerequisites for building relations with customers are: sales promotion, higher quality control of complaints, and creating personalized loyalty programs.

A hotel manager can make a decision on which customer segment will focus its marketing and promotional activities, in order to increase the overall impact on the most profitable ones, by creating a personalized message based on the previously collected information from (gender, age, smoker, non smoker allergic to feathers, etc...). Furthermore, CRM and PMS systems (Property Manage- ment System) allow better monitoring and responding to customer complaints. "People who complain indicate that the company has some operational or management problems that must be corrected. Therefore, they offer a free gift, and act as advisors who diagnose company problems for free."[5] PMS offers the possibility to simplify the monitoring of complaints (when did they occur, who made a complaint, etc ...) and can assist managers in making decisions about which strategy to apply. Thus, if the manager knows that the customer who complained belongs to the group of the most rewarding guests, and that, for example, he likes to drink a certain type of wine in the hotel, the manager can easily choose a strategy of compensation, and thus compensate for his emotional or time costs.

Finally, CRM and PMS systems can facilitate hotelier's job of creating a loyalty program, or provide it with an option for their improvement. " Loyalty programs are a special form of discounts, special lower price, and amenities within the product"[6]. Based on different information (from which way of booking a guest prefer, to what kind of daily press he or she likes to read) managers have the opportunity for maximum personalization of the loyalty program. Tendencies towards an individualization of services exist, but the information technology almost daily provide opportunities for its successful creation.

\section{CONCLUSION}

Information Technology impact and change the way we work and make decisions in business intensively. "Information is a critical resource for tourism, and therefore information systems play a very important role in improving the competitiveness and success of tourism enterprises and destinations, as well as strengthening the overall tourism demand"[2]. Growth and development of information technology will certainly continue in the future. Simultaneously, service users will become more demanding because they are actively using IT daily. "As a result, in the future, differentiation from the competition will be based on the speed, with which the company manages to meet the demands and needs of the market for innovative products and services" [8].

In front of the hotel managers is a big challenge, and it is a successful way of building relationships with their customers, and creating their long-term loyalty. This paper presents some of the ways in which information technology can serve hoteliers in the process of making these decisions.

\section{REFERENCES}

[1] Rađenović M., Razvoj IT kao podrška donošenju odluka u hotelskim kompanijama, Hotelska Kuća, Zlatibor 2013. p. 399

[2] Njeguš A., Informacioni sistemi u turističkom poslovanju, Univerzitet Singidunum Beograd, 2013. pp. 221-404

[3] Čačić K.,Poslovanje hotelskih preduzeća, Univerzitet Singidunum Beograd, 2011. p.312 
[4] Živković R., Ponašanje i zaštita potrošača u turizmu, Univerzitet Singidunum Beograd, 2013. p.165

[5] Živković R., Gajić J., Aleksić A., Strategije hotelskog preduzeća u situacijama nezadovoljstva korisnika usluga, Hotelska kuća, Zlatibor 2013. p. 239

[6] Pavlović T., Sektor soba, FRAME Media, Beograd 2011.p. 65

[7] Mohammed A. A., Customer Relationship Management (CRM) in Hotel Industry: A framework Proposal on the Relationship among CRM Dimensions, Marketing Capabilities and Hotel Performance, International Review of Management and Marketing Vol. 2, No. 4, 2012, pp.220-230

[8] Sotoudeh M., Customer Relationship Management in the Tourism industry of Iran, Lulea University of Technology, master thesis, 2006. p. 15 